\title{
Fractional Composition of Organic Matter and Properties of Humic Acids in the Soils of Drained Bogs of the Siedlce Heights in Eastern Poland
}

\author{
Marcin Becher', Wojciech Tołoczko², Agnieszka Godlewska ${ }^{3 *}$, \\ Krzysztof Pakuła', Emil Żukowski ${ }^{1}$ \\ 1 Faculty of Agrobioengineering and Animal Husbandry, Siedlce University of Natural Sciences and Humanities, \\ ul. B. Prusa 14, 08-110 Siedlce, Poland \\ 2 Sub-Department of Environmental Dynamics and Soil Science, Department of Physical Geography University \\ of Łódz, ul. Narutowicza 88, 90-139 Łódź, Poland \\ 3 Faculty of Medical and Health Sciences, Siedlce University of Natural Sciences and Humanities, ul. B. Prusa 14, \\ 08-110 Siedlce, Poland \\ * Corresponding author's e-mail: godlewskaa@uph.edu.pl
}

\begin{abstract}
The studied bogs of the Siedlce Heights in eastern Poland are currently undergoing decession. In the course of pedological studies, a significant modification of the structure of soil profiles caused by the murshing process was found. The total contents of carbon and nitrogen values $(\mathrm{TC} / \mathrm{TN}=11.1-17.3)$ obtained in the study, as well as slight acidification $\left(\mathrm{pH}_{\mathrm{KC}} 5.42-6.15\right)$ indicate the eutrophy of the studied soil environment, high biological activity and a significant degree of organic matter processing as a result of the processes of mineralization and humification. In addition, the upper levels covered by the process of murshing, compared to peat, are characterized by lower carbon content and, most often, similar nitrogen content. In the studied soils, humic substances are mostly represented by the fraction of humic acids. As a consequence, high values of the quotient expressing quantitative relations between soil humus fractions (HAs/FAs) were noted. For all profiles, the highest share of fulvic acids was recorded in turf murshic levels (M1). The occurrence of the most mature humic acids was found in the peat levels not covered by secondary transformation processes after dehydration.
\end{abstract}

Keywords: secondary transformation process, humification, carbon fractions, sequential extraction.

\section{INTRODUCTION}

In Poland, peat bogs occupy about 12.5 thousand $\mathrm{km}^{2}$, which is approx. $4 \%$ of the country area. The protective function of marsh areas and peat bogs completely flooded with water should be noted, because very little $\mathrm{CO}_{2}$ is emitted into the atmosphere - in the winter months approx. $200 \mathrm{mg}\left(\mathrm{CO}_{2}\right) \cdot \mathrm{m}^{-2} \cdot \mathrm{h}^{-1}$, and in the summer months approx. $700 \mathrm{mg}\left(\mathrm{CO}_{2}\right) \cdot \mathrm{m}^{-2} \cdot \mathrm{h}^{-1} \quad$ [Tołoczko and Niewiadomski, 2017]. Unfortunately, during the drainage process, some hydrogenic habitats were incorporated into agricultural production areas. Moreover, in the process of river regulation and industrial investments, about $90 \%$ of non-forest peat bogs in Poland were drained [Ostrowski and Dembek, 2012]. The consequence of lowered groundwater level is weakening of its preservative effect in relation to the organic matter accumulated in the peat-forming process. Oxidation of the top layers of peat results in an extremely intensive transformation of the soil cover of the drained wetland areas, which is called murshing in the literature. This process leads to the formation of murshic levels with different morphology as well as physical, chemical and biological properties in comparison to the parent peat. The scope of changes in organic soil morphology and 
modification of soil material properties covered by this process are the basis for distinguishing organic murshic soils [Kabała et al. 2019].

The most important effect of the murshing process is mineralization of organic matter, as a result of which the elements bound in it are released. The effects of this phenomenon go beyond the soil environment, because they affect the chemistry of the hydrosphere (eutrophication) and the atmosphere (greenhouse effect). Mineralization of drained peat under Polish conditions ranges from 5.0 to $17.8\left(\mathrm{Mg} \cdot \mathrm{ha}^{-1} \cdot \mathrm{rok}^{-1}\right)$ [Jurczuk, 2011]. The pace and extent of changes in the soil cover on peatlands used for agriculture depends on the hydrological conditions and fluctuations in groundwater, as well as the way in which these soils are utilised. The pro-ecological use should consist in maintaining permanent grassland, with well-rooted turf, while maintaining the groundwater table during the growing season at an average depth of $32 \mathrm{~cm}$ [Piaścik and Gotkiewicz, 2004]. It may result in a sustainable balance of organic matter, but it requires efficiency in the area of irrigation [Jurczuk, 2011].

Soil humic substances are part of the organic matter constituting a mixture of amorphous, dark-coloured polydisperse compounds of various origins, relatively resistant to degradation processes. They are formed in the process of humification, i.e. the microbiological process of transformation of organic compounds. The share of humic substances in peat mass indicates the degree of its distribution [Ilnicki, 2002]. The process of murshing occurring after dehydration of the peat deposit determines the far-reaching quantitative and qualitative changes in the composition of organic matter. Intensive mineralization is accompanied by humification that increases the content of humic substances in the top soil levels [Kalisz et al. 2010; Becher 2013].

The Siedlce Heights is one of the poorest mesoregions of the Southern Podlasie Lowland - the rate of peat extraction equals $3.1 \%$. Almost exclusively, there are low peats here, with a relatively large share of rush beds and very small moss deposits [Dembek, 2000]. Origination of the most extensive peat bogs is associated with the occurrence of melt pits and end mounds of the Warta Stage moraines in the area of the upper course of the Liwiec River $\left(13.78 \mathrm{~km}^{2}\right)$ and the Muchawka River $\left(16.30 \mathrm{~km}^{2}\right)$ [Dembek et al. 2000]. The peatbogs formed in large melt pools are wetlands with various types of hydrological feeding: soligenous-fluviogenic, soligenous-pressure, fluviogenic [Dembek et al. 2000].

The fluviogenic and soligenous-fluviogenic bogs are dominated with fresh grass meadows (Arrhenatheretalia), as well as wet meadows of the stalks and grasslands (communities with meadow grassland - Poa pratensis, and meadow foxtail-Alopecurus pratensis) and grassy-prairie meadows. In the dome zone, wet sedge meadows (Cirsietum rivularis with horsetail) and sedgemoss meadows (Scheuchzerio Caricetea-fuscae) prevail [Dembek et al. 2000].

The information on the murshic levels formed in the peat deposits in river valleys of this mesoregion was provided as early as during the development of the drainage and meadow characterization in the middle of the last century. Currently, the peat bogs of the Siedlce Heights remain in the phase of decession, i.e. in the negative balance of organic matter [Becher, 2013, Becher et al. 2013, Becher et al. 2020]. The aim of the research was to determine the fractional composition and direction of transformation of organic matter of peat-murshic soils created from various peat species using the example of research stands located in the Siedlce Heights in eastern Poland.

\section{MATERIALS AND METHODS}

\section{Research site and morphological features of the studied soils}

Field pedological studies were conducted in the autumn of 2016 in the wetland areas of the Siedlce Heights (318.94), which is part of the Southern Podlasie Lowland (318.9). The landscape is dominated by terminal and bottom moraines. The average elevation is $160 \mathrm{~m}$ above sea level, and the maximum reaches $200 \mathrm{~m}$ [Solon et al. 2018]. The Siedlce Heights (318.94) is a vast mesoregion formed by moraine clays and loamy sands. The arable soils are occupied here by arable fields dominated by complexes 4 and 5 agricultural suitability of soils [Tołoczko, 2020]. The largest peat bog areas are located in the south-eastern part of the mesoregion. The research covered three profiles of soils made of various types of peat, located in the valley of the upper course of the Liwiec River and the Muchawka River (Figure 1). They 
were as follows: Hemi-murshic organic soil (profile I), made from peat moss $\left(52^{\circ} 06^{\prime} 12^{\prime} \mathrm{N}\right.$, $22^{\circ} 37^{\prime} 06^{\prime} \mathrm{E}$ ); Hemi-murshic organic soil (profile II), made from sedge peat $\left(52^{\circ} 03^{\prime} 33^{\prime \prime} \mathrm{N}\right.$, $\left.22^{\circ} 19^{\prime} 36^{\prime \prime} \mathrm{E}\right) ; \quad$ Sapri-murshic organic soil (profile III), made from oles peat $\left(52^{\circ} 10^{\prime} 54^{\prime \prime} \mathrm{N}\right.$, $\left.22^{\circ} 28^{\prime} 34^{\prime \prime} \mathrm{E}\right)$. The morphological characteristics of the studied soil objects according to the principles of Polish Soil Classification [Kabała et al. 2019] are presented in Table 1.

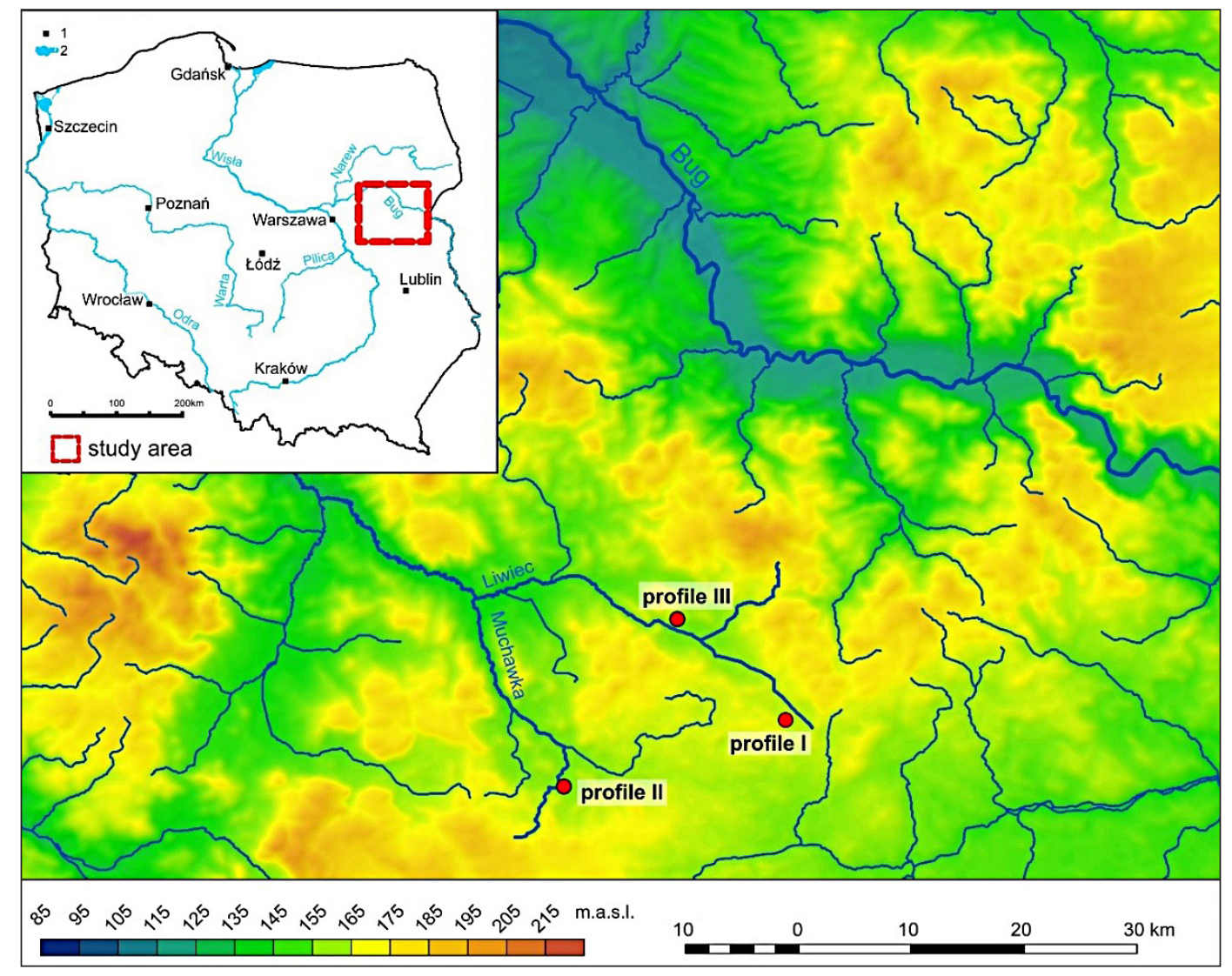

Figure 1. Location of the studied soil profiles in Poland

Table 1. Morphological features of the studied soils

\begin{tabular}{|c|c|c|}
\hline Profile number & Genetic level, depth & Morphological features \\
\hline I & $\begin{array}{l}\text { M1 }(0-10 \mathrm{~cm}) \\
\text { M2 }(10-20 \mathrm{~cm}) \\
\text { M3 }(20-35 \mathrm{~cm}) \\
\text { Oe1 }(36-60 \mathrm{~cm}) \\
\text { Oe2 }(60-90 \mathrm{~cm}) \\
\text { Cg }(90-110)\end{array}$ & $\begin{array}{l}\text { - murshic, very fine / fine, grainy structure; } \\
\text { - murshic, medium / thick, grainy structure; } \\
\text { - organic mass cracked, very coarse structure; } \\
\text { - peat rut, hemic, R2, coarse, fibrous structure; } \\
\text { - peat rut, hemic, R2, coarse, fibrous structure; } \\
\text { - sandy loam (gp); } \\
\text { ground water level: } 80 \mathrm{~cm} \text { below the surface }\end{array}$ \\
\hline II & $\begin{array}{l}\text { M1 }(0-8 \mathrm{~cm}) \\
\text { M2 }(8-20 \mathrm{~cm}) \\
\text { Oe1 }(20-40 \mathrm{~cm}) \\
\text { Oe2 }(40-70 \mathrm{~cm}) \\
\text { Cg }(70-90 \mathrm{~cm})\end{array}$ & $\begin{array}{l}\text { - murshic, very fine, grainy structure; } \\
\text { - murshic, medium and granular structure; } \\
\text { - sedge peat, sapric, R2, fine structure, fibrous; } \\
\text { - sedge peat, hemic, R2, fine and fibrous structure; } \\
\text { - loamy sand; } \\
\text { ground water level: } 65 \mathrm{~cm} \text { below the surface }\end{array}$ \\
\hline III & $\begin{array}{l}\text { M1 }(0-9 \mathrm{~cm}) \\
\text { M2 }(9-22 \mathrm{~cm}) \\
\text { M3 }(22-35 \mathrm{~cm}) \\
\text { Oa1 }(35-55 \mathrm{~cm}) \\
\text { Oa2 }(55-65 \mathrm{~cm}) \\
\text { Cg }(65-85 \mathrm{~cm})\end{array}$ & $\begin{array}{l}\text { - murshic, very fine, grainy structure; } \\
\text { - murshic, fine / medium, grainy structure; } \\
\text { - organic mass cracked, medium structure; } \\
\text { - oles peat, sapric, R3, piece structure; } \\
\text { - highly silted peat, sapric, R3; } \\
\text { - clay dust; } \\
\text { ground water level: } 70 \mathrm{~cm} \text { below the surface }\end{array}$ \\
\hline
\end{tabular}




\section{Soil properties}

During fieldwork, the soil samples of undisturbed structure were collected into cylinders (volume $100 \mathrm{~cm}^{3}$ ) in order to determine the dry bulk density of the dry soil $(D)$. The density of the soil solid phase $\left(D_{w}\right)$ was calculated on the basis of crude ash content $(M)$, using the relationship described by the regression equation: $D_{w}=1.451$ $+11 M,(r=0.960)$ [Okruszko 1993]. General porosity $(P)$ was calculated as follows: $P=\left(D_{w}\right.$ $-D) / D_{w} \cdot 100 \%$ [Bednarek et al. 2004]. The soil samples representing organic genetic levels were dried at $40^{\circ} \mathrm{C}$, then ground in a porcelain mortar and screened through a sieve $(\varnothing=2.0 \mathrm{~mm})$. For laboratory analyses, a representative part of the sample of the collective test material was ground in an agate mortar (down to $\varnothing<0.25 \mathrm{~mm}$ ). The following laboratory analyses were performed: ash (crude ash content), determined by weight, after burning soil material in a muffle furnace at $550^{\circ} \mathrm{C}$ [Allen 1989]; soil $\mathrm{pH}$ was determined by potentiometric $\mathrm{pH}$ measurement in $1 \mathrm{M} \mathrm{KCl}$, with air dry soil to solution ratio of $1: 5(\mathrm{v} / \mathrm{v})$; the total contents of carbon (TC) and nitrogen (TN) were determined using a Series II 2400 autoanalyzer (Perkin Elmer, thermal conductivity detector
- TCD; acetanilide as reference material); the content of organic matter $(\mathrm{OM})$ was calculated: $\mathrm{OM}=\mathrm{TC} 1,724$.

\section{Fractioning of organic matter}

Sequential fractionation of organic matter was carried out, based on the Schnitzer method [Becher et al. 2013, Becher et al. 2021] - Figure 2. The name, symbol and procedure for obtaining the organic matter fraction are presented in Table 2. The results of the sequential analysis are presented in the form of the carbon content of the fraction and as the content of carbon of the fraction in the total carbon content ( $\% \mathrm{TC})$. The carbon ratio of fulvic to humic acids (HAs/FAs) was calculated.

\section{Humic acids (HAs) properties}

Preparations of humic acids were carried out according to the Schnitzer procedure. The ash content (after roasting at $600^{\circ} \mathrm{C}$ ) in the preparations of humic acids was $0.98-1.49 \%$. The following tests were carried out: elemental composition $(\mathrm{C}$, $\mathrm{H}$ and $\mathrm{N}$ content - in the elemental analysis selfanalyser, $\mathrm{O}$ content was determined from the difference). The atomic ratio $\mathrm{H} / \mathrm{C}$ and the degree of

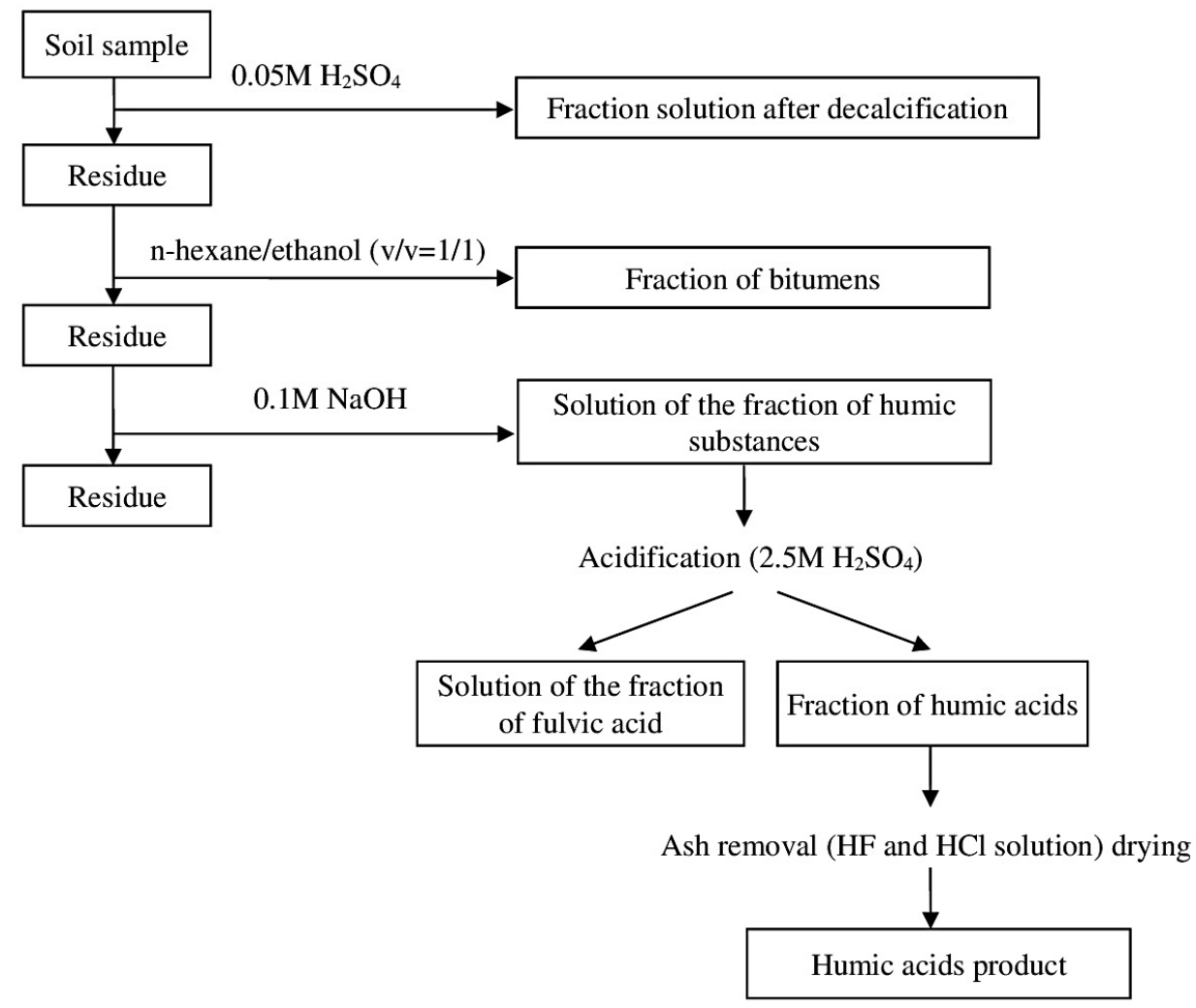

Figure 2. Diagram of sequential fractionation of organic matter 
Table 2. Fractions of organic matter (organic carbon) and the method of their extraction

\begin{tabular}{|c|c|}
\hline Operetional carbon fractions & Procedure \\
\hline $\begin{array}{l}\text { Fraction after decalcification } \\
\text { Lab-C }\end{array}$ & $\begin{array}{l}\text { Extraction with } 0.05 \mathrm{M} \mathrm{H}_{2} \mathrm{SO}_{4} \text {; extraction time } 24 \mathrm{~h} ; \mathrm{m} / \mathrm{v}=1 / 50 \text {; centrifugation }(\mathrm{g} \\
=4000 \mathrm{rpm}) \text { and filtration through a cellulose filter. Carbon in the solution was } \\
\text { determined by the oxidative and titration method [Kalembasa 1991]. }\end{array}$ \\
\hline $\begin{array}{l}\text { Lipid fraction } \\
\text { Lip-C }\end{array}$ & $\begin{array}{l}\text { Extraction (ethanol }+n \text {-hexane, v/v=1/1) in an automatic solvent extractor } \\
\text { Soxterm (Gerhard). The weight of the bitumens was determined by weighting. } \\
\text { Carbon was determined with an elemental analyser. }\end{array}$ \\
\hline $\begin{array}{l}\text { Humus substance fractions } \\
\text { HS-C }\end{array}$ & $\begin{array}{l}\text { Extraction with } 0.1 \mathrm{M} \mathrm{NaOH} \text {; extraction time }=24 \mathrm{~h} ; \mathrm{m} / \mathrm{v}=1 / 50 \text {; centrifugation }(\mathrm{g} \\
=4000 \mathrm{rpm}) \text { and filtration through a cellulose filter. Carbon in the solution was } \\
\text { determined by the oxidative and titration method. }\end{array}$ \\
\hline $\begin{array}{l}\text { Fulvic acid fractions } \\
\text { FAs-C }\end{array}$ & $\begin{array}{l}\text { Acidification }(2.5 \mathrm{M} \mathrm{H} 2 \mathrm{SO} 4, \mathrm{pH}=1.80) \text { of the measured out extraction part } 0.1 \mathrm{M} \\
\mathrm{NaOH} \text {. After humic acid precipitation and sedimentation }(24 \mathrm{~h}) \text { in a solution of } \\
\text { fulvic acids, carbon was determined by the oxidative and titration method. }\end{array}$ \\
\hline $\begin{array}{l}\text { Humic acid fraction } \\
\text { HAs-C }\end{array}$ & Calculation: $\mathrm{HAs}-\mathrm{C}=\mathrm{HS}-\mathrm{C}-\mathrm{FAs}-\mathrm{C}$ \\
\hline $\begin{array}{l}\text { Residual fraction (post-extraction residue) } \\
\text { Res-C }\end{array}$ & Calculation: Res-C $=\mathrm{TC}-($ Lab-C + Lip-C + HS-C $)$ \\
\hline
\end{tabular}

internal oxidation of particles were calculated on the basis of the atomic share: $\omega=[(2 \mathrm{O}+3 \mathrm{~N})-\mathrm{H}] / \mathrm{C}$ [Zdanov 1965]; spectrophotometric properties of a solution of humic acids $(0.02 \%$ in $0.05 \mathrm{M} \mathrm{NaH}-$ $\mathrm{CO}_{3}$ ), in a Lambda 25 spectrophotometer (Perkin Elmer). The absorbance measurements were made at wavelength (in nm): $400\left(A_{400}\right), 465\left(A_{465}\right), 600$ $\left(A_{600}\right)$ and $665\left(A_{665}\right)$. The following were calculated: absorbance quotient $A_{4 / 6}\left(A_{465} / A_{665}\right)$ [Chen et al. 1977]; $\Delta \log K=\log A_{400}-\log A_{600}$ [Kumada 1988]. Laboratory analyses were performed in triplicate. The test results were referenced to the absolute dry matter, which was determined by weight after drying at $105^{\circ} \mathrm{C}$.

\section{Statistical analysis}

The statistical calculations were made using the STATISTICA 13 PL statistical software (TIBCO Software, PaloAlto, CA, USA). Descriptive statistics were used for characterization of the population: arithmetic mean, minimum value, maximum value, standard deviation, coefficient of variation. The relationships between the studied features are expressed in the form of the simple correlation coefficient $(r)$ - in selected cases the linear regression equation was determined.

\section{RESULTS AND DISCUSSION}

A distinctive morphological feature of the studied soils is the clear formation of the murshic (turf - M1 and underturf - M2) levels with a permanent crumb structure. In profile I and III, the third level of murshic was diagnosed (with the initial murshing phase -M3), built of cracked organic matter and intermediate features between the upper murshic layer and the deeper overhanging peat. In profile III, significant sedimentation of pitched alder peat was found. Differentiation of morphological features of the studied soils as a result of the mowing process was confirmed by the results of physical properties analysis (Table 3 ).

Assessment of the degree of mineral content in organic soils concerns the ash content obtained after burning the material at high temperature [Ilnicki, 2002]. The murshic level of the studied soils, accordingly to the advancement of murshing, showed a tendency to increase the ash content. On the other hand, peat levels showed clear associations with individual peat groups (rush $<$ sedge $<$ alder) and degree of decomposition (hemic $<$ sapric). These observations are common in the subject literature [Ilnicki 2002, Becher 2013].

In the case of bulk density - a parameter that measures the degree of soil compaction - a similar variability was observed as in the case of ash. With increased depth of sample origin, a reduction in the degree of soil compaction was usually observed (with a modifying effect of the silting process in profile III). Compaction of dehydrated organic soils may occur not only directly, as a result of the process of murshing, but also secondarily through the iluvation and vertilisation of the finely divided murshic body in the crevices formed when the dehydrated organic mass breaks [Okruszko, 1993].

Soil porosity is a feature that determines the retention of organic soils, and the amount of individual pores is related to the soil density and the degree of transformation of organic material [Becher 2013, Glina et. al. 2016]. According to 
Table 3. Physical properties and reaction of the studied soils

\begin{tabular}{|c|c|c|c|c|c|}
\hline Profile number & Genetic level, depth & Crude ash (\%) & Bulk density $\left(\mathrm{g} \cdot \mathrm{cm}^{-3}\right)$ & General porosity (\%) & $\mathrm{pH}_{\mathrm{Kc}}$ \\
\hline \multirow{5}{*}{ I } & M1 $(0-10 \mathrm{~cm})$ & 27.5 & 0.355 & 79.8 & 5.42 \\
\hline & M2 $(10-20 \mathrm{~cm})$ & 29.4 & 0.323 & 81.8 & 5.80 \\
\hline & M3 $(20-35 \mathrm{~cm})$ & 17.7 & 0.288 & 82.5 & 5.88 \\
\hline & Oe1 $(35-60 \mathrm{~cm})$ & 10.0 & 0.161 & 89.7 & 5.84 \\
\hline & Oe2 (60-90 cm) & 10.3 & 0.164 & 89.5 & 5.66 \\
\hline \multirow{4}{*}{ II } & M1 $(0-8 \mathrm{~cm})$ & 24.8 & 0.286 & 83.4 & 6.15 \\
\hline & M2 (8-20 cm) & 31.9 & 0.329 & 81.7 & 6.13 \\
\hline & Oa1 $(20-40 \mathrm{~cm})$ & 16.0 & 0.240 & 85.2 & 5.51 \\
\hline & Oe2 $(40-70 \mathrm{~cm})$ & 12.1 & 0.185 & 88.3 & 5.66 \\
\hline \multirow{5}{*}{ III } & M1 (0-9 cm) & 27.1 & 0.319 & 81.8 & 5.81 \\
\hline & M2 (9-22cm) & 24.9 & 0.298 & 82.7 & 5.58 \\
\hline & M3 (22-35 cm) & 33.8 & 0.300 & 83.5 & 5.74 \\
\hline & Oa1 $(35-55 \mathrm{~cm})$ & 23.5 & 0.201 & 88.2 & 5.62 \\
\hline & Oa2 $(55-65 \mathrm{~cm})$ & 51.7 & 0.301 & 85.1 & 5.76 \\
\hline
\end{tabular}

common observations, significantly higher volume fraction of soil pores was found in the studied soils in peat levels, in relation to murshic areas. It is also known that in surface levels constituting the rhizosphere of soils, general porosity (as well as the bulk density) can be modified by the presence of numerous roots, root canals and soil fauna activity [Okruszko, 1993; Caldwell et al. 2007].

Measurement of the $\mathrm{pH}$ value of soil suspensions in $1 \mathrm{M} \mathrm{KCl}$ solution showed little variation of this parameter, both between the studied soils and in soil profiles. The $\mathrm{pH}_{\mathrm{KCl}}$ values were recorded in accordance with the recommendations of Okruszko [1993]; the examined soils are defined as medium acidic. The information found in the literature [Okruszko, 2000] concerning higher peat $\mathrm{pH}$ in relation to the mire (mainly due to leaching of alkaline cations) has not been confirmed in the studied soils.

The studies have shown that murshic levels are characterized by a lower content of carbon as compared to peat (as a consequence of organic matter) and lower values of the TC/TN ratio (Table 4). The nitrogen content was characterized by low profile variability (Table 4). One of the most characteristic phenomena in the mowing process is the decrease in the carbon content due to mineralization of organic compounds in the oxygenated

Table 4. Content of carbon, nitrogen and the value of TC/TN

\begin{tabular}{|c|c|c|c|c|c|}
\hline Profile number & Genetic level, depth & $\mathrm{TC}\left(\mathrm{g} \cdot \mathrm{kg}^{-1}\right)$ & Organic matter $\left(\mathrm{g} \cdot \mathrm{kg}^{-1}\right)$ & $\mathrm{TN}\left(\mathrm{g} \cdot \mathrm{kg}^{-1}\right)$ & $\mathrm{TC} / \mathrm{TN}$ \\
\hline \multirow{5}{*}{ I } & M1 (0-10 cm) & 364.1 & 627.7 & 29.9 & 12.2 \\
\hline & M2 (10-20 cm) & 371.2 & 639.9 & 29.1 & 12.8 \\
\hline & M3 (20-35 cm) & 452.2 & 779.6 & 29.8 & 15.2 \\
\hline & Oe1 $(35-60 \mathrm{~cm})$ & 508.7 & 877.0 & 31.1 & 16.4 \\
\hline & Oe2 (60-90 cm) & 502.9 & 867.0 & 29.2 & 17.2 \\
\hline \multirow{4}{*}{ II } & M1 (0-8 cm) & 383.1 & 660.5 & 32.9 & 11.6 \\
\hline & M2 (8-20 cm) & 360.2 & 621.0 & 29.8 & 12.1 \\
\hline & Oa1 $(20-40 \mathrm{~cm})$ & 469.8 & 809.9 & 33.1 & 14.2 \\
\hline & Oe2 (40-70 cm) & 507.9 & 875.6 & 32.3 & 15.7 \\
\hline \multirow{5}{*}{ III } & M1 $(0-9 \mathrm{~cm})$ & 385.0 & 663.7 & 34.8 & 11.1 \\
\hline & M2 (9-22cm) & 398.9 & 687.7 & 34.9 & 11.4 \\
\hline & M3 $(22-35 \mathrm{~cm})$ & 372.8 & 642.7 & 26.8 & 13.9 \\
\hline & Oa1 $(35-55 \mathrm{~cm})$ & 439.7 & 758.0 & 25.4 & 17.3 \\
\hline & Oa2 (55-65 cm) & 227.9 & 392.9 & 15.7 & 14.5 \\
\hline
\end{tabular}


top part of the soil profile. It is followed by the migration of carbon to the atmosphere in oxidized $\left(\mathrm{CO}_{2}\right)$ form. The nitrogen content stays at a level similar to the "initial" (i.e. before the protective action of water is removed), or its secondary accumulation (compaction) may occur in the mass of the forming mound [Okruszko, 1993; Becher, 2013]. As a consequence of the transformation of carbon and nitrogen compounds in the process of murshing, the ratio of carbon to nitrogen is narrowed. The quantitative relation of these elements, expressed in the form of $\mathrm{C} / \mathrm{N}$ values, is an important indicator of the biochemical direction of organic matter, because at low values (below $20)$ it accelerates the rate of mineralization of organic matter [Okruszko, 1993].

In the studied soils, the TC/TN value is reduced according to the degree of organic matter processing - from the highest values in peat levels to significantly lower levels in murshic beds. The values of this parameter in the murshic soil levels of the studied soils are similar to the those in arable soils found in humus horizons, characterized by highly transformed organic matter and good conditions for its transformation [Turski, 1988, Bednarek et al. 2004]. The TC/TN values (11.1-17.3) obtained in the study, as well as slight acidification $\left(\mathrm{pH}_{\mathrm{KCl}}\right.$ 5.42-6.15) indicate the eutrophy of the studied soil environment, high biological activity and a significant degree of organic matter processing as a result of the processes of mineralization and humification.

\section{Fractional composition of organic matter}

The obtained test results were presented in the form of the content and share of carbon (in TC) determined in individual organic matter fractions (Tables 5 and 6).

In the studied soils, the fraction with the least quantitative importance, at the same time characterized by the highest variability, is the one separated in the first fractionation step (using $0.05 \mathrm{M}$ $\mathrm{H}_{2} \mathrm{SO}_{4}$ ) - named after decalcification (Lab-C). This fraction is mainly represented by simple organic compounds with low molecular weight, potentially labile in the soil environment and susceptible to mineralization [Stevenson, 1994; Becher, 2013]. In murshic levels, as compared to peat, more than twice the share of carbon in this fraction was found, on average.

Conversely to the fraction after decalcification, in the murshic peat levels in relation to the peat, a significantly smaller share of carbon belonging to the soil bitumen fraction (lipid fraction) was clearly observed. The fraction separated with organic solvents is made up, among other things, of waxes, tars, resins, fatty acids and their esters, and many other compounds of an aliphatic character and high energy value [Neves et al. 2009]. In the studied soils, there was a tendency to increase the proportion of this fraction with the depth. Scientific research indicates that the share of bitumens in peat soils depends on the degree of decomposition and type of peat [Becher, 2013]. Literature reports also suggest that the

Table 5. Carbon content of organic matter fraction

\begin{tabular}{|c|c|c|c|c|c|c|c|}
\hline \multirow{2}{*}{$\begin{array}{l}\text { Profile } \\
\text { number }\end{array}$} & \multirow{2}{*}{ Genetic level, depth } & Lab-C & Lip-C & HS-C & FAs-C & HAs-C & Res-C \\
\hline & & \multicolumn{6}{|c|}{$\mathrm{g} \cdot \mathrm{kg}^{-1}$} \\
\hline \multirow{5}{*}{1} & M1 $(0-10 \mathrm{~cm})$ & 1.78 & 15.0 & 166.4 & 29.6 & 136.8 & 180.9 \\
\hline & M2 (10-20 cm) & 1.89 & 16.5 & 175.2 & 29.1 & 146.1 & 177.6 \\
\hline & M3 (20-35 cm) & 1.03 & 22.5 & 165.1 & 24.4 & 140.6 & 263.6 \\
\hline & Oe1 $(35-60 \mathrm{~cm})$ & 0.90 & 33.9 & 92.1 & 16.8 & 75.2 & 381.8 \\
\hline & Oe2 $(60-90 \mathrm{~cm})$ & 0.70 & 30.3 & 72.9 & 13.6 & 59.3 & 399.0 \\
\hline \multirow{4}{*}{ II } & M1 $(0-8 \mathrm{~cm})$ & 2.09 & 10.4 & 157.8 & 35.0 & 122.9 & 212.8 \\
\hline & M2 $(8-20 \mathrm{~cm})$ & 1.76 & 12.2 & 155.2 & 32.0 & 123.2 & 191.0 \\
\hline & Oa1 (20-40 cm) & 1.30 & 21.1 & 106.2 & 12.7 & 93.4 & 341.2 \\
\hline & Oe2 $(40-70 \mathrm{~cm})$ & 1.51 & 29.6 & 89.9 & 13.7 & 76.2 & 386.9 \\
\hline \multirow{5}{*}{ III } & M1 $(0-9 \mathrm{~cm})$ & 2.76 & 11.0 & 180.2 & 33.8 & 146.3 & 191.0 \\
\hline & M2 (9-22cm) & 2.55 & 9.8 & 193.1 & 31.0 & 162.0 & 193.5 \\
\hline & M3 $(22-35 \mathrm{~cm})$ & 1.29 & 11.8 & 149.5 & 25.9 & 123.6 & 213.9 \\
\hline & Oa1 $(35-55 \mathrm{~cm})$ & 0.48 & 20.5 & 124.9 & 20.2 & 104.6 & 293.8 \\
\hline & Oa2 $(55-65 \mathrm{~cm})$ & 0.71 & 12.8 & 72.5 & 15.8 & 56.7 & 141.9 \\
\hline
\end{tabular}


Table 6. The share of carbon in the organic matter fraction of the studied soils: ratio of humic to fulvic carbon

\begin{tabular}{|c|c|c|c|c|c|c|c|c|}
\hline \multirow{2}{*}{$\begin{array}{l}\text { Profile } \\
\text { number }\end{array}$} & \multirow{2}{*}{ Genetic level, depth } & Lab-C & Lip-C & $\mathrm{HS}-\mathrm{C}$ & FAs-C & HAs-C & Res-C & \multirow{2}{*}{$\begin{array}{l}\text { HAs-C } \\
\text { /FAs-C }\end{array}$} \\
\hline & & \multicolumn{6}{|c|}{$\%$ TC } & \\
\hline \multirow{5}{*}{ I } & M1 $(0-10 \mathrm{~cm})$ & 0.490 & 4.13 & 45.7 & 8.13 & 37.6 & 49.7 & 4.62 \\
\hline & M2 $(10-20 \mathrm{~cm})$ & 0.510 & 4.44 & 47.2 & 7.85 & 39.4 & 47.9 & 5.01 \\
\hline & M3 $(20-35 \mathrm{~cm})$ & 0.228 & 4.98 & 36.5 & 5.40 & 31.1 & 58.3 & 5.76 \\
\hline & Oe1 $(35-60 \mathrm{~cm})$ & 0.177 & 6.66 & 18.1 & 3.31 & 14.8 & 75.1 & 4.47 \\
\hline & Oe2 $(60-90 \mathrm{~cm})$ & 0.139 & 6.03 & 14.5 & 2.71 & 11.8 & 79.3 & 4.35 \\
\hline \multirow{4}{*}{ II } & M1 $(0-8 \mathrm{~cm})$ & 0.546 & 2.72 & 41.2 & 9.13 & 32.1 & 55.5 & 3.51 \\
\hline & M2 $(8-20 \mathrm{~cm})$ & 0.489 & 3.38 & 43.1 & 8.89 & 34.2 & 53.0 & 3.85 \\
\hline & Oa1 $(20-40 \mathrm{~cm})$ & 0.276 & 4.49 & 22.6 & 2.71 & 19.9 & 72.6 & 7.34 \\
\hline & Oe2 $(40-70 \mathrm{~cm})$ & 0.297 & 5.83 & 17.7 & 2.69 & 15.0 & 76.2 & 5.58 \\
\hline \multirow{5}{*}{ III } & M1 $(0-9 \mathrm{~cm})$ & 0.718 & 2.87 & 46.8 & 8.79 & 38.0 & 49.6 & 4.32 \\
\hline & M2 $(9-22 \mathrm{~cm})$ & 0.639 & 2.46 & 48.4 & 7.78 & 40.6 & 48.5 & 5.22 \\
\hline & M3 $(22-35 \mathrm{~cm})$ & 0.347 & 3.17 & 40.1 & 6.94 & 33.2 & 56.4 & 4.78 \\
\hline & Oa1 $(35-55 \mathrm{~cm})$ & 0.109 & 4.67 & 28.4 & 4.60 & 23.8 & 66.8 & 5.17 \\
\hline & $\mathrm{Oa} 2(55-65 \mathrm{~cm})$ & 0.310 & 5.63 & 31.8 & 6.92 & 24.9 & 62.3 & 3.60 \\
\hline
\end{tabular}

biological activity of soils, combined with intensified organic matter mineralization, leads to a reduction in the share of carbon that can be separated by organic solvents [Turski, 1988; Becher, 2013]. Some authors also see the reason for the variation in the amount of bitumen carbon in soils in the reactions of fatty acid saponification with calcium and magnesium cations present in soils [Wiesenberg et al. 2004].

The carbon extracted from the soil samples with alkaline solution $(0.1 \mathrm{M} \mathrm{NaOH})$ represents humic substances (HS-C), fulvic (FAs-C) and humic (HAs-C) acids. The carbon content of humic substances showed high profile variability related to the advancement of the organic matter humification process. Thus, in murshic beds, an average of twice the share of carbon in the alkaline extract was found. As expected, rush peat and sedge peat (hemic material) were characterized by a lower proportion of humic substances compared to peat moss (sapric material). The research of other authors shows that, in addition to the humification process taking place "in situ", the elution and iluvation of humified organic mass in macropores formed as a result of physical diagenesis of drained peat and the intensifying, washable type of water management in the upper soil horizons may also constitute an additional factor differentiating the share of humic substances [Okruszko, 1993; Piaścik and Gotkiewicz, 2004).

In the studied soils, humic substances are mostly represented by the fraction of humic acids, the properties of which largely determine the quality of organic matter [Weber et al. 2018]. As a consequence, high values of the quotient expressing quantitative relations between soil humus fractions were noted (HAs-C/FAs-C). For all profiles, the highest share of fulvic acids was recorded in turf murshic levels (M1). One of the distinguishing features of the murshic process is, among other things, intense humification of peat organic matter [Okruszko, 1993, Becher, 2013]. In the outer turf levels (M1), which are also the zone of intensive rooting of plants (rhizosphere), there is also a significant and successive inflow of organic matter from dead roots and above-ground parts of meadow vegetation. Due to the (nonpeat) source of organic matter, but also good oxygenation of this part of the profile, intensive degradation processes occur, resulting in the formation of fulvic acids. The studies on the processes of decomposition of organic residues show that the initial stages of humification are characterized by the intense production of fulvic acids [Dębska et al. 2009; Becher. 2013]. Okruszko and Kozakiewicz [1973] state that the fraction of fulvic acids increases in the murshic levels, and it has a significant relationship with the rate of changes caused by dehydration - in heavily rotting soils, the predominance of fulvic acid fraction moves to the level adjacent to the parent peat. In the studied soils, there was no noticeable as part of the "deepening of murshic effects" transfer of the zone of 
the largest share of fulvic acids to deeper arid murshic levels [Piaścik and Gotkiewicz, 1995].

Organic matter fractionation proved that in the studied soils, humification mainly favours the formation of humic acids, i.e. the humus fraction composed of high-molecular and relatively stable organic compounds [Stevenson, 1994]. This is expressed in the values of the carbon ratio of humic acids to fulvic acids (HAs-C/FAs-C) ranging from 3.51 to 7.34 . The direction of organic matter transformation - found in the studied soils - is characteristic of the soils made of peat and currently evolving under the pressure of dehydration, which is confirmed by other researchers [Kalisz et al. 2010, Becher et al. 2013]. A certain distinctness among peat levels concerning the fractional composition of organic matter (also the physical and chemical properties discussed before) is revealed by the bottom levelled, silted level of alder peat (profile III). In this level, compared to the peat level deposited directly above it, a higher proportion of humic substances and lower HAs-C/FAs-C value were found. Dembek [2000] stated that in the area of the location of this profile, under the modern Holocene peat deposit, buried, older and more decomposed late Pleistocene organic sediments are found. This may explain the occurrence of a strongly silted peat level in the base of this soil, characterized by a higher content of humic substances and other features that demonstrate a stronger decomposition of organic matter.

Inversely to the degree of organic matter processing of the studied soils, along with the depth a tendency of increasing the amount of carbon included in the residual fraction (post-extraction residue Res-C) was observed. According to the authors' suggestions [Turski, 1988], the carbon of this fraction in the soils where solid phase formation is associated with the accumulation of organic debris in the swamp process and with the inflow of fresh organic matter from the current plant formation should be classified as the unhumified organic matter, rather than the humin fraction (the most resistant to decomposition of humus substances, strongly associated with the mineral part of the solid phase). In these soils, there is usually no mineral clay fraction - a factor potentially "fixing" humic substances through the possibility of forming permanent organic-mineral bonds [Stevenson, 1994]. The fraction includes organic remains resistant to microbial decomposition, containing, among others, lignin, cellulose and hemicellulose, derived from peat-forming vegetation and additionally (in top peat levels) from the current meadow vegetation.

The values of linear correlation coefficients presented in Table 7 show significant relationships between the physical and chemical properties characterizing the degree of organic matter decomposition as well as advancement of the murshing process and qualitative features of organic matter, expressed in its fractional composition. Particularly strong correlations were found in the relationship between the share of the distinguished fractions of organic matter and the bulk density, total porosity and the $\mathrm{TC} / \mathrm{TN}$ ratio. The processes of organic matter decomposition in the studied soils significantly favour the accumulation of the most labile carbon fraction after decalcification and carbon representing humic substances (positive significant correlation with volumetric and negative density with porosity and TC/TN ratio). In addition, the values of coefficients suggest that the process of murshing and progressive decomposition of organic matter is not conducive to the accumulation of carbon in hydrophobic organic compounds extracted with organic solvents (soil bitumens).

Table 7. Values of the share of carbon in the organic matter fractions and the ratio of humic acids to fulvic acids

\begin{tabular}{|l|c|c|c|c|c|c|c|c|}
\hline \multirow{2}{*}{ Statistical measure } & Lab-C & Lip-C & HS-C & FAs-C & HAs-C & Res-C & HAs-C \\
\cline { 2 - 10 } & \multicolumn{7}{|c|}{$\%$ TC } & \multicolumn{7}{c|}{ /Fs-C } \\
\hline Average & 0.377 & 4.39 & 34.4 & 6.13 & 28.3 & 60.8 & 4.83 \\
\hline Minimal & 0.109 & 2.46 & 14.5 & 2.69 & 11.8 & 47.9 & 3.51 \\
\hline Maximal & 0.718 & 6.66 & 48.4 & 9.13 & 40.6 & 79.3 & 7.34 \\
\hline Standard deviation & 0.190 & 1.34 & 12.2 & 2.49 & 9.88 & 11.2 & 1.00 \\
\hline Coefficient of variation (\%) & 50.4 & 30.5 & 35.3 & 40.6 & 34.9 & 18.5 & 20.6 \\
\hline Average for peat levels & 0.218 & 5.55 & 22.2 & 3.82 & 18.4 & 72.0 & 0.218 \\
\hline Average for murshic levels & 0.496 & 3.52 & 43.6 & 7.86 & 35.8 & 52.4 & 0.496 \\
\hline
\end{tabular}




\section{Properties of humic acids}

The presented results concerning humic acids clearly indicate that their properties are related to the place of their occurrence in the soil profile (table 8 and 9). In the murshic horizons, as compared to the peat horizons, the share of carbon and oxygen atoms was lower, and that of hydrogen and nitrogen atoms higher. As a reflection of the elemental composition, higher values of $\mathrm{H} / \mathrm{C}$ ratios and lower degrees of internal oxidation were obtained in the upper levels - the parameter $\omega$, taking into account the entire elemental composition of organic compounds. Similarly, humic acids of the upper murshic horizons showed clearly higher values of spectrophotometric parameters. In general, along with the increase in depth, a clear tendency of increasing the proportion of carbon atoms, decreasing hydrogen (as a consequence of reducing the $\mathrm{H} / \mathrm{C}$ value) and decreasing the values of $A_{4 / 6}$ and $\Delta \log K$ was found.

Research into the chemical nature of humic acids suggests that these substances in advanced stages of humification ("mature"), characterized by a higher molecular weight and a greater degree of condensation of aromatic elements of the structure, show lower values of spectrometric coefficients in the research, compared to the acids in the initial stages of humification ("young") [Chen et al. 1977, Kumada, 1988, Dębska, 2004]. The value of the $\mathrm{H}: \mathrm{C}$ quotient is inversely proportional to the aromaticity of organic compounds which build humic acids [Dębska, 2004]. The obtained results clearly suggest that the humic acids of the murshic levels, in comparison to the peat levels, show a lower degree of humification, i.e. they are less "mature", with a lower molecular

Table 8. Elemental composition and spectrophotometric parameters of humic acids in the studied soils

\begin{tabular}{|c|c|c|c|c|c|c|c|c|c|}
\hline \multirow{2}{*}{ Profile No. } & \multirow{2}{*}{ Genetic level, depth } & C & $\mathrm{H}$ & $\mathrm{O}$ & $\mathrm{N}$ & \multirow{2}{*}{$\mathrm{H} / \mathrm{C}$} & \multirow{2}{*}{$\omega$} & \multirow{2}{*}{$A_{4 / 6}$} & \multirow{2}{*}{$\Delta \log K$} \\
\hline & & \multicolumn{4}{|c|}{ atomic $\%$ * } & & & & \\
\hline \multirow{5}{*}{ I } & M1 $(0-10 \mathrm{~cm})$ & 36.4 & 42.0 & 19.0 & 2.62 & 1.15 & 0.107 & 5.10 & 0.741 \\
\hline & M2 (10-20 cm) & 36.7 & 41.2 & 19.6 & 2.50 & 1.12 & 0.146 & 4.99 & 0.727 \\
\hline & M3 $(20-35 \mathrm{~cm})$ & 38.4 & 39.9 & 19.7 & 1.99 & 1.04 & 0.143 & 4.92 & 0.710 \\
\hline & Oe1 $(35-60 \mathrm{~cm})$ & 39.1 & 38.8 & 19.9 & 2.17 & 0.992 & 0.190 & 4.81 & 0.694 \\
\hline & Oe2 $(60-90 \mathrm{~cm})$ & 39.9 & 38.6 & 19.5 & 2.01 & 0.966 & 0.159 & 4.49 & 0.640 \\
\hline \multirow{4}{*}{ II } & M1 (0-8 cm) & 36.4 & 41.3 & 19.7 & 2.60 & 1.13 & 0.160 & 4.99 & 0.721 \\
\hline & M2 (8-20 cm) & 36.6 & 40.8 & 20.1 & 2.56 & 1.12 & 0.195 & 4.86 & 0.700 \\
\hline & Oa1 $(20-40 \mathrm{~cm})$ & 38.7 & 38.9 & 20.2 & 2.25 & 1.00 & 0.212 & 4.66 & 0.670 \\
\hline & Oe2 $(40-70 \mathrm{~cm})$ & 39.4 & 38.5 & 20.1 & 1.98 & 0.978 & 0.191 & 4.46 & 0.629 \\
\hline \multirow{5}{*}{ III } & M1 (0-9 cm) & 35.2 & 42.7 & 19.2 & 2.90 & 1.21 & 0.124 & 5.22 & 0.758 \\
\hline & M2 (9-22cm) & 36.0 & 41.8 & 19.7 & 2.53 & 1.16 & 0.144 & 5.13 & 0.749 \\
\hline & M3 $(22-35 \mathrm{~cm})$ & 37.8 & 39.8 & 20.3 & 2.02 & 1.05 & 0.181 & 4.74 & 0.680 \\
\hline & Oa1 (35-55 cm) & 39.3 & 38.2 & 20.8 & 1.71 & 0.973 & 0.218 & 4.70 & 0.670 \\
\hline & $\mathrm{Oa} 2(55-65 \mathrm{~cm})$ & 38.9 & 38.4 & 20.5 & 2.16 & 0.987 & 0.232 & 4.47 & 0.629 \\
\hline
\end{tabular}

Table 9. Values of descriptive statistics for the elemental composition and spectrophotometric parameters of humic acids

\begin{tabular}{|c|c|c|c|c|c|c|c|c|}
\hline \multirow{2}{*}{ Statistical measure } & C & $\mathrm{H}$ & $\mathrm{O}$ & $\mathrm{N}$ & \multirow{2}{*}{$\mathrm{H} / \mathrm{C}$} & \multirow{2}{*}{$\omega$} & \multirow{2}{*}{$A_{4 / 6}$} & \multirow{2}{*}{$\Delta \log K$} \\
\hline & \multicolumn{4}{|c|}{ atomic \% * } & & & & \\
\hline Average & 37.8 & 40.1 & 19.9 & 2.29 & 1.06 & 0.172 & 4.82 & 0.694 \\
\hline Minimal & 35.2 & 38.2 & 19.0 & 1.71 & 0.966 & 0.107 & 4.46 & 0.629 \\
\hline Maximal & 39.9 & 42.7 & 20.8 & 2.90 & 1.21 & 0.232 & 5.22 & 0.758 \\
\hline Standard deviation & 1.52 & 1.53 & 0.496 & 0.333 & 0.084 & 0.037 & 0.250 & 0.043 \\
\hline Coefficient of variation (\%) & 4.03 & 3.83 & 2.50 & 14.6 & 7.86 & 21.4 & 5.18 & 6.21 \\
\hline Average for peat levels & 39.2 & 38.6 & 20.1 & 2.05 & 0.983 & 0.200 & 4.60 & 0.655 \\
\hline Average for murshic levels & 36.7 & 41.2 & 19.7 & 2.46 & 1.12 & 0.150 & 4.99 & 0.723 \\
\hline
\end{tabular}

\footnotetext{
* - by weight without ash content
} 
weight and lesser condensation of the aromatic part of their structure. The humic acids isolated from peat horizons showed the $\mathrm{H} / \mathrm{C}$ values below unity, which may indirectly indicate a greater share of aromatic structures than aliphatic ones in the structure of their molecules. A greater share of nitrogen in humic acids in murshic levels (well-oxygenated and biologically active zones of the profile) may be the result of higher "availability" of simple nitrogen forms at the condensation stage of the humification process. The fact of incorporating a significant part of mineralized nitrogen into the structure of humic substances in the murshic process is described in the literature [Okruszko, 1993, Kalbitz and Geyer, 2002, Becher, 2013].

The common feature of the humic acids isolated from the upper levels of the studied soils (M1) corresponds to the values of the parameters described, which clearly indicate their lowest "maturity" in the profile. It may be a result of the humification process of organic compounds systematically flowing in from meadow vegetation (dead above-ground and underground parts). Scientific research on the dynamics of changes in the parameters of humic acids at various stages of organic matter decomposition confirms that this suggestion is true [Dębska, 2004].

The above-mentioned suggestions are confirmed by the values of the correlation coefficients presented in Tables 10 and 11 for the properties of genetic levels and humic acids isolated from them. Particularly strong correlations were demonstrated for the quality traits of humic acids with soil properties typically variable in the processes of murshing of the tested organic soils: bulk density, total porosity, $\mathrm{TC} /$ $\mathrm{TN}$ value and the degree of decomposition expressed as the proportion of humic substances. Therefore, it can be suggested that as part of the process of murshing and transformation of organic matter, humic acids were formed with a lower carbon content, and more hydrogen and nitrogen, and with a higher $\mathrm{H} / \mathrm{C}$ ratio and spectrophotometric parameters.

The basic feature of the studied soils is the high variability of the share of individual organic

Table 10. Values of linear correlation coefficients $(r)$ between the carbon share of the organic matter fraction, the carbon ratio of humic acids to fulvic acids and the properties of the genetic levels of the studied soils

\begin{tabular}{|c|c|c|c|c|c|c|c|}
\hline Parameter & Crude ash & Bulk density & $\begin{array}{c}\text { General } \\
\text { porosity }\end{array}$ & $\mathrm{pH}_{\mathrm{KCI}}$ & $\mathrm{TC}$ & $\mathrm{TN}$ & $\mathrm{TC} / \mathrm{TN}$ \\
\hline Lab-C & 0.371 & $0.745^{* *}$ & $-0.765^{* *}$ & 0.205 & -0.468 & 0.420 & $-0.964^{* *}$ \\
\hline Lip-C & -0.362 & $-0.696^{* *}$ & $0.726^{* *}$ & -0.209 & 0.406 & -0.376 & $0.829^{* *}$ \\
\hline HS-C & $0.570^{*}$ & $0.920^{* *}$ & $-0.918^{* *}$ & 0.210 & $-0.638^{*}$ & 0.134 & $-0.861^{* *}$ \\
\hline FAs-C & $0.667^{* *}$ & $0.880^{* *}$ & $-0.833^{* *}$ & 0.421 & $-0.745^{* *}$ & 0.011 & $-0.857^{* *}$ \\
\hline HAs-C & $0.533^{*}$ & $0.910^{* *}$ & $-0.920^{* *}$ & 0.153 & -0.597 & 0.162 & $-0.843^{* *}$ \\
\hline Res-C & $-0.580^{*}$ & $-0.924^{* *}$ & $0.920^{* *}$ & -0.206 & $0.649^{*}$ & -0.107 & $0.849^{* *}$ \\
\hline HAs-C/FAs-C & -0.471 & -0.233 & 0.105 & $-0.561^{*}$ & $0.518^{*}$ & 0.337 & 0.235 \\
\hline
\end{tabular}

Critical values $(\mathrm{n}=14): 0.532(*-$ at $\alpha=0.05) ; 0.661(* *-$ at $\alpha=0.01)$

Table 11. Values of linear correlation coefficients ( $r$ ) between the tested parameters of humic acids and the properties of genetic levels of the studied soils

\begin{tabular}{|c|c|c|c|c|c|c|}
\hline Parameter & Bulk density & $\begin{array}{c}\text { General } \\
\text { porosity }\end{array}$ & TC & TC/TN & $\begin{array}{c}\text { The share of humic } \\
\text { substances (HS-C) }\end{array}$ & HAs-C/FAs-C \\
\hline$C$ & $-0.808^{* *}$ & $0.847^{* *}$ & 0.459 & $0.955^{* *}$ & $-0.913^{* *}$ & 0.275 \\
\hline$H$ & $0.760^{* *}$ & $-0.831^{* *}$ & -0.341 & $-0.904^{* *}$ & $0.869^{* *}$ & -0.248 \\
\hline$N$ & $0.665^{* *}$ & $-0.702^{* *}$ & -0.384 & $-0.907^{* *}$ & $0.688^{* *}$ & -0.315 \\
\hline$O$ & -0.317 & 0.440 & -0.093 & 0.476 & -0.346 & 0.135 \\
\hline$H / C$ & $0.780^{* *}$ & $-0.835^{* *}$ & -0.398 & $-0.933^{* *}$ & $0.890^{* *}$ & -0.268 \\
\hline$\omega$ & -0.443 & $0.574^{*}$ & -0.043 & 0.515 & $-0.548^{*}$ & 0.092 \\
\hline$A_{4 / 6}$ & $0.639^{* *}$ & $-0.735^{* *}$ & -0.197 & $-0.764^{* *}$ & $0.816^{* *}$ & -0.121 \\
\hline$\Delta \log K$ & $0.622^{* *}$ & $-0.725^{* *}$ & -0.167 & $-0.755^{* *}$ & $0.801^{* *}$ & -0.091 \\
\hline
\end{tabular}

Critical values $(\mathrm{n}=14): 0.532(*-$ at $\alpha=0.05) ; 0.661(* *-$ at $\alpha=0.01)$ 
matter fractions, between the studied soil objects and, above all, the profile variability in individual soil units. This diversity is related to the degree of advancement of the humification process (the degree of decomposition) of the organic matter of the parent forms and the intensification of the murshing process. Reed peat and sedge peat moss showed the features of materials less well distributed in relation to alder peat. The change in the properties of the investigated soils in the direction appropriate to the process of murshing, i.e. increase in the ash content and soil compaction, reduction of soil pores and organic matter decomposition processes, clearly favour the increase in the proportion of humic substances, with a simultaneous decrease in the ratio of humic to fulvic carbon.

In the studied soils, the most important quantitative effect of the transformation of organic matter is the formation of relatively stable compounds classified as humic acids. The extent of transformation of organic matter depends on the degree of peat decomposition and the degree of the murshing process. The source of substrates necessary for the synthesis of humic substances is related to the depth of the genetic level. It may be organic matter accumulated at the stage of the swamp process (in deeper soil levels) and the ecosystem from the vegetation (in murshic beds).

A very important effect of the transformation of organic matter in well-oxygenated murshic beds is the higher proportion of potentially labile organic compounds in the soil environment, i.e. low-molecular simple organic compounds (decalcification fraction), and also less stable humus fraction - fulvic acids. Decomposition and humification of organic material of the studied soils is not conducive to soil accumulation of soil bitumens. Organic matter metabolism was significantly associated with a comprehensive change in their physical and chemical characteristics. Selected relationships are shown graphically in the form of regression equations (Figures 3, 4, 5 and 6).

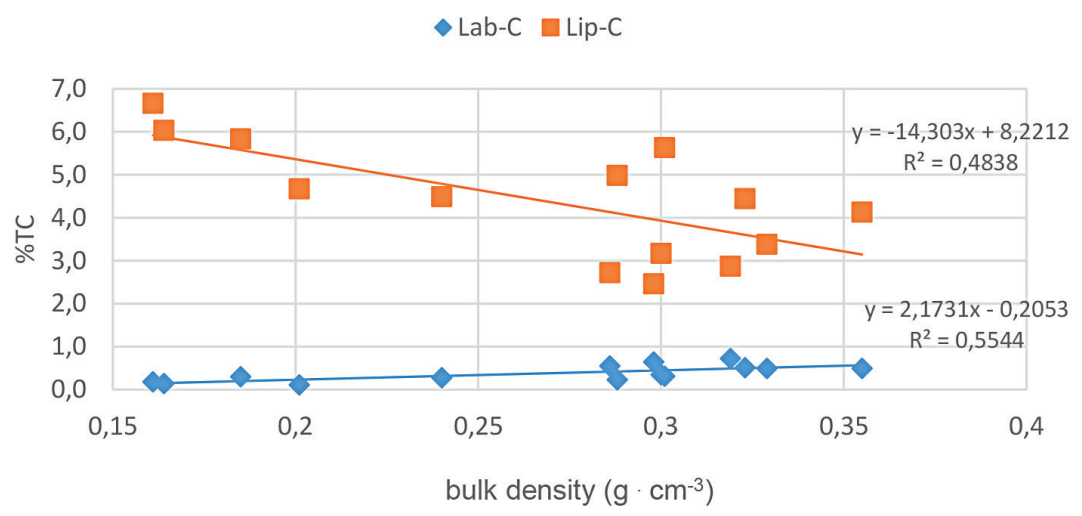

Figure 3. Relationship between the share of carbon in the fraction after decalcification, bitumen and soil volumetric density

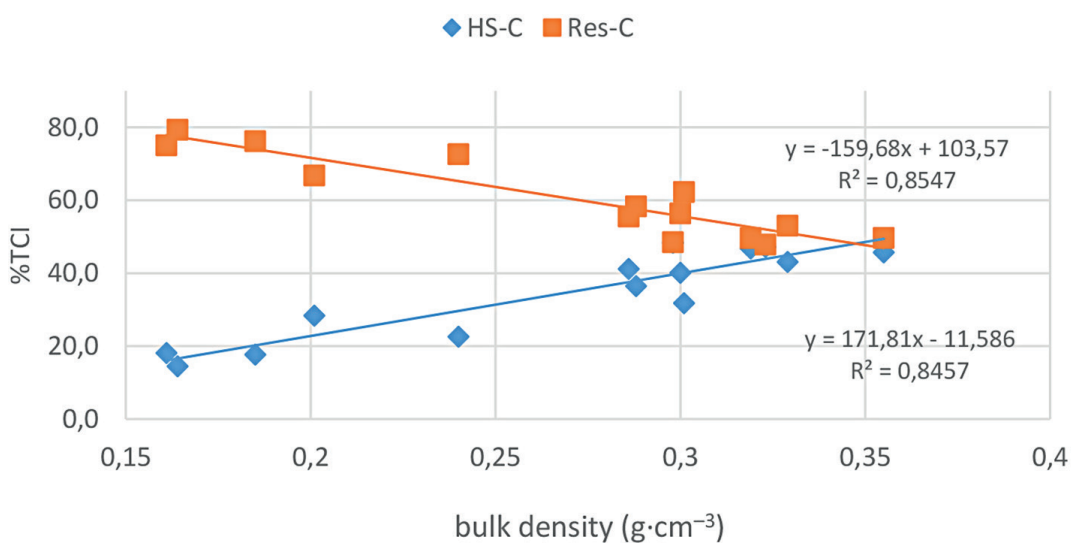

Figure 4. Relationship between the carbon share of humic substances, post-extraction residue and the soil volume density 


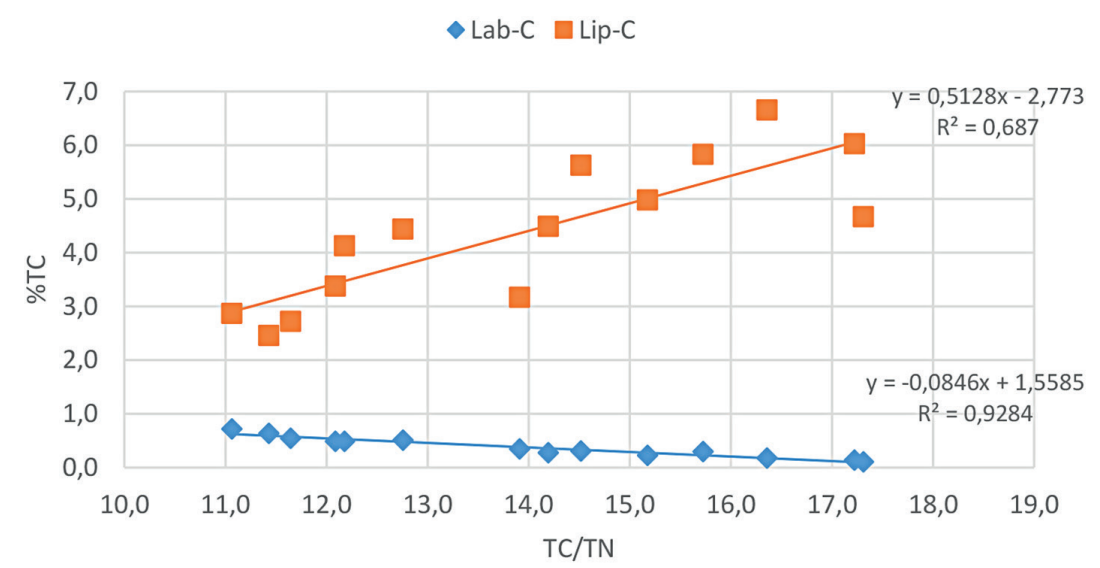

Figure 5. Relationship between the carbon share of humic substances, post-extraction residue and the $\mathrm{TC} / \mathrm{TN}$ ratio

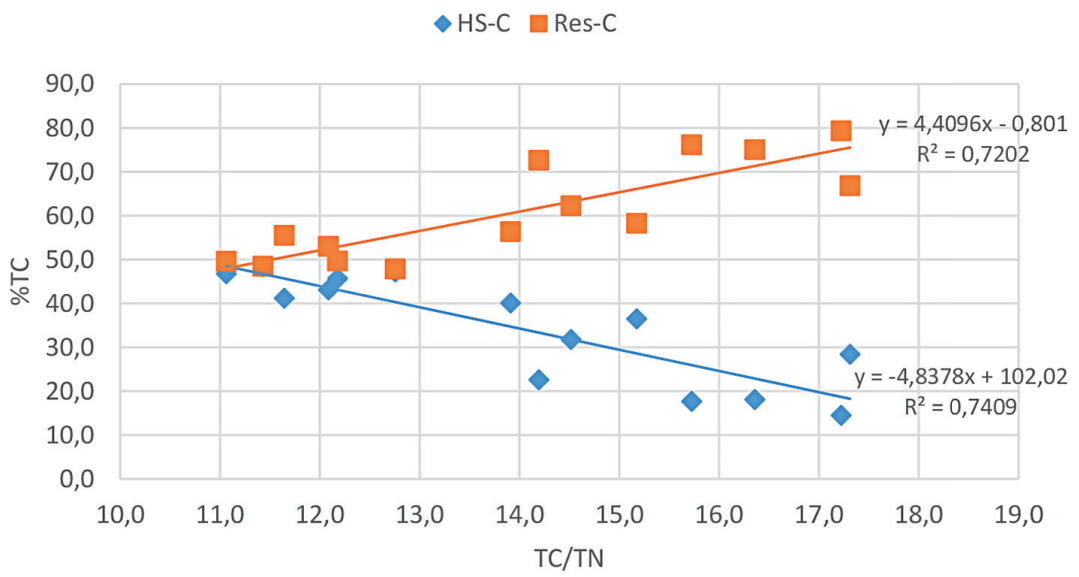

Figure 6. Relationship between the carbon share of humic substances, post-extraction residue and the TC / TN ratio

\section{CONCLUSIONS}

The studied bogs of the Siedlce Heights are currently undergoing decession. In the course of pedological studies, a significant modification of the structure of soil profiles caused by the murshing process was found. Murshic levels, in relation to peat moss, show a higher content of crude ash and higher density, which at the same time correlates with a lower proportion of soil pores. In addition, the upper levels covered by the process of murshing, compared to peat, are characterized by lower carbon content and, most often, similar nitrogen content.

Intensive biochemical changes leading to the qualitative changes in organic matter in murshic levels have also been expressed by the narrowing of carbon-nitrogen $(\mathrm{C} / \mathrm{N})$ quantitative relations. The resulting diversification of physical and chemical properties of the studied soils is also a consequence of the different types of peat from which the studied soils were formed. During the research, the high natural status of organic soils was confirmed in the aspect of the accumulation of organic matter. The results of the research indicate a significant eutrophy of the studied soils, their drying and high degree of organic matter processing and significant biological activity, expressed by intensive mineralization and humification.

The properties of humic acids in the studied soils depend on the place of their formation in the soil profile, which is related to the humification conditions, and in particular to the source of organic compounds necessary for its occurrence. This is the organic matter accumulated in the peat forming process (primary), and additionally in the murshic soil levels of the studied soils, originating from the vegetation of the current ecosystem. Meadow vegetation is the most important determinant shaping the quality of humic acids 
in turf murshic levels, where the humic acids characteristic for materials of the initial stages of humification were found. The occurrence of the most mature humic acids was found in the peat levels not covered by secondary transformation processes after dehydration.

\section{Acknowledgments}

This research was supported under the research theme no. 35/20/B by the Ministry of Science and Higher Education.

\section{REFERENCES}

1. Allen S.E. 1989. Chemical Analysis of Ecological Materials, 2nd edn. Blackwell Scientific Publications, Oxford, UK.

2. Becher M. 2013. The state of transformation of organic matter in the soils of the upper Liwiec river valley. Rozprawa naukowa, 125, Wyd. UP-H w Siedlcach, 158. (in Polish).

3. Becher M., Kalembasa D., Pakuła K., Malinowska E. 2013. Carbon and nitrogen fractions in drained organic soils. Environmental Protection and Natural Resources, 24, 4(58), 1-5.

4. Becher M., Pakuła K., Jaremko D. 2020. Phosphorus Accumulation in the Dehydrated Peat Soils of the Liwiec River Valley. Journal Ecological Enginering, 21(5), 213-220.

5. Becher M., Banach-Szott M., Godlewska A. 2021. Organic matter properties of spent button mushroom substrate in the context of soil organic matter reproduction. Agronomy, 11(2), 204.

6. Bednarek R., Dziadowiec H., Pokojska U., Prusinkiewicz Z. 2004. Ecological and soil science research. PWN, Warszawa, 343. (in Polish)

7. Caldwell P.V., Vepraskas M.J., Gregory J.D. 2007. Physical properties of natural organic soils in Carolina Bays of the Southeastern United States. Soil Science Society of America Journal, 71, 1051-1057.

8. Chen Y., Senesi N., Schnitzer M. 1977. Information provided on humic substances by $\mathrm{E}_{4 / 6}$ rations. Soil Science Society of America Journal, 41, 352-358.

9. Dembek W. 2000. Selected aspects of peatland diversity in young- and old-glacial landscapes of eastern Poland. Rozprawy habilitacyjne, IMUZ, 175. (in Polish)

10. Dembek W., Piórkowski H., Rycharski M. 2000. Wetlands against the background of physico-geographical regionalization of Poland. Biblioteczka Wiadomości IMUZ, 97, 135. (in Polish)

11. Dębska B. 2004. Properties of humic substances in soil fertilized with manure slurry. ATR Bydgoszcz, Rozprawy, 110, 112. (in Polish)
12. Dębska B., Szombathová, N., Banach-Szott M. 2009. Properties of humic acids of soil under different management regimes. Polish Journal of Soil Science, 42(2), 131-138.

13. Glina B., Gajewski P., Kaczmarek Z., Owczarzak W., Rybczyński P. 2016. Current state of peatland soils as an effect of long-term drainage - preliminary results of peatland ecosystems investigation in the Grójecka Valley (central Poland). Soil Science Annual, 67(1), 3-9.

14. Ilnicki P. 2002. Peat bogs and peat. AR Poznań, 606. (in Polish)

15. Jurczuk S. 2011. Meliorative conditions for the preservation of organic matter in post-bog meadows. Woda-Środowisko-Obszary Wiejskie. Rozprawy naukowe i monografie, 30, 81. (in Polish)

16. Kabała C., Charzyński P., Chodorowski J., Drewnik M., Glina B., Greinert A., Hulisz P., Jankowski M., Jonczak J., Łabaz B., Łachacz A., Marzec M., Mendyk Ł., Musiał P., Musielok Ł., Smreczak B., Sowiński P., Świtoniak M., UzarowiczŁ., Waroszewski J. 2019. Polish Soil Classification, 6th edition - principles, classification scheme and correlations. Soil Science Annual, 70(2), 71-97.

17. Kalbitz K., Geyer S. 2002. Different effects of peat degradation on dissolved organic carbon and nitrogen. Organic Geochemistry, 33(3), 319-326.

18. Kalembasa S. 1991. Quick method of determination of organic carbon in soil. Polish Journal of Soil Science, 24(1), 17-22.

19. Kalisz B., Łachacz A., Glażewski R. 2010. Transformation of some organic matter components in organic soils exposed to drainage. Turkish Journal of Agriculture and Forestry, 34(3), 245-256.

20. Kumada K. 1988. Chemistry of soil organic matter. Japan Sc. Soc. Press Tokyo, Elsevier Amsterdam-Oxford-New York-Tokyo, Developments in Soil Science 17, 241.

21. Neves L., Ferreira V., Oliveira R. 2009. Co-composting cow manure with food waste: The influence of lipids content. World Academy of Science, Engineering and Technology, 58, 986-991.

22. Okruszko H., Kozakiewicz A. 1973. Humification and mineralization as murshing process elements in peat soils. Zeszyty Problemowe Postępów Nauk Rolniczych, 146, 63-76. (in Polish)

23. Okruszko H. 1993. Transformation of fen-peat soils under the impast of draining. Zeszyty Problemowe Postępów Nauk Rolniczych, 406, 3-73.

24. Okruszko H. 2000. Phenomenon of peat soil degradation in the light of experiments. Acta Agrophysica, 26, 7-15.

25. Ostrowski J., Dembek W. 2012. History and development of studies on wetland identification and protections at the Institute of Technology and Life 
Sciences. Woda-Środowisko-Obszary Wiejskie, 12, 4(40), 217-238. (in Polish)

26. Piaścik H., Gotkiewicz J. 1995. Degradation processes in the drained peatlands of the post-glacial areas. Zeszty Problemowe Postępów Nauk Rolniczych, 418(1), 185-190. (in Polish)

27. Piaścik H., Gotkiewicz J. 2004. Transformation of dewatered peat soils as the cause of their degradation. Soil Science Annual, 55(2), 331-338. (in Polish)

28. Solon J., Borzyszkowski J., Bidłasik M., Richling A., Badora K., Balon J., Brzezińska-Wójcik T., Chabudziński Ł., Dobrowolski R., Grzegorczyk I., Jodłowski M., Kistowski M., Kot R., Krąż P., Lechnio J., Macias A., Majchrowska A., Malinowska E., Migoń P., Myga-Piątek U., Nita J., Papińska E., Rodzik J., Strzyż M., Terpiłowski S., Ziaja W. 2018. Physicogeographical mesoregions of Poland: Verifi cation and adjustment of boundaries on the basis of contemporary spatial data. Geographia Polonica, 91(2), 143-170.

29. Stevenson F.J. 1994. Humus Chemistry: genesis, composition, reactions. Wiley, NY, 512 pp.
30. Tołoczko W., Niewiadomski A. 2017. Seasonal and daily variability of $\mathrm{CO}_{2}$ emissions from the Czerwone Bagno peat bog in Biebrza National Park (Poland). Polish Journal of Soil Science, 50(2), 217-235.

31. Tołoczko W. 2020. Arable soils of physico-geographic macro- and mesoregions of Poland. UŁ, Łódź, 178. (in Polish)

32. Turski R. 1988. Characteristics of humus compounds in the soils of Poland. PWN, Warszawa, 69. (in Polish)

33. Weber J., Chen Y., Jamroz E., Miano T. 2018. Preface: Humic substances in the environment. Journal of Soils Sediments, 18, 2665-2667.

34. Wiesenberg G.L.B., Schwark L., Schmidt W.I. 2004. Improved automated extraction and separation procedure for soil lipid analyses. Europen Journal of Soil Science, 55, 349-356.

35. Zdanov J.A. 1965. Medium carbon oxidation and amino acid indispensability. Biochimija, 30(6), 1257-1259. (in Russian). 